\title{
GENERATION OF RENEWABLE ENERGY ON CLOSED LANDFILLS TO COMPENSATE FOR BIOGAS EMISSIONS: A CASE STUDY IN THE VALDINA LANDFILL (MESSINA, ITALY)
}

\author{
CALABRÒ P.S. ${ }^{1, *}$ \\ LISI R. ${ }^{2}$
}

\author{
${ }^{1}$ Università degli Studi Mediterranea di Reggio Calabria \\ Department of Civil, Energy, Environmental and Materials Engineering \\ via Graziella - loc. Feo di Vito, Reggio Calabria, 89122, Italy \\ ${ }^{2}$ Messinambiente spa, Via Dogali 50, Messina, 98122, Italy
}

Received: 01/03/2014

Accepted: $28 / 12 / 2014$

Available online: 14/01/2014 *to whom all correspondence should be addressed: e-mail: paolo.calabro@unirc.it

\section{ABSTRACT}

The contribution of integrated municipal solid waste (MSW) management systems to greenhouse gas emissions is not negligible, even though it is moderate compared with other anthropogenic activities. The main emission from landfills that accept biodegradable MSW is methane that escapes from the biogas collection system. Such emissions are partially compensated if the collected biogas is exploited for energy production. Further compensation measures would also increase the overall sustainability of the landfill site. This study analyses the possibility of exploiting closed landfills to produce energy based on the case study of the Valdina landfill (Messina, Italy). Two possible scenarios are presented: the installation of a photovoltaic system and the cultivation of giant reed (Arundo donax L.) to be used for energy production through combustion. The results of a preliminary experimental activity are presented for the second scenario. The findings demonstrate the possibility of using the leachate produced in the landfill for irrigation purposes. For each scenario, the costs, potential energy production rate, avoided emissions and issues related to the integration of energy production with the landfill aftercare are evaluated. The presented results suggest that the cultivation of giant reed is the best option, especially during the early post-closure period, in terms of investment $(18,000 €$ against $8,300,000 €)$, high production yield in the Mediterranean climate, simplicity of cultivation and integration with ordinary post-closure landfill management, limited cost of the energy produced $\left(0.1 € \mathrm{kWh}^{-1}\right.$ against $\left.0.27 € \mathrm{kWh}^{-1}\right)$. On the other hand avoided emissions are higher for the photovoltaic plant $\left(27804 \mathrm{t}_{\mathrm{CO}_{2}}\right.$ against $778 \mathrm{t}_{\mathrm{CO}_{2}}$ on an horizon of 20 years).

Keywords Biogas, Giant reed, Greenhouse gases, Landfill, Municipal waste, Solar energy

\section{Introduction}

The contribution of integrated municipal solid waste (MSW) management systems to greenhouse gas emissions is moderate compared with other anthropogenic activities; however, it is not negligible. Landfills that accept biodegradable MSW release methane which is produced by anaerobic microorganisms. This gas escapes from the biogas collection system and enters the atmosphere through landfill surface. In order to reduce these emissions, EU regulations (Directive 1999/31/EC; Official Journal of the European Community, 1999), which have been adopted in Italy (Gazzetta Ufficiale della Repubblica Italiana, 2003), stipulate the progressive reduction of the landfilling of municipal biodegradable waste. This reduction can be achieved both by separate collection and by thermal or mechanical/biological treatment before landfilling. In addition, if the collected biogas is exploited for energy production, the 
greenhouse gas emissions from landfills are partially compensated. Further compensation measures can also increase overall landfill sustainability. Based on the foregoing, this study analyzes the possibility of exploiting landfills, after their closure, to produce energy. In particular, the case study of the Valdina landfill (Messina, Sicily, Italy) is investigated.

The scientific literature reports several examples of the exploitation of closed landfills for energy production. In particular, the production of biomass destined to produce energy is relatively well documented (e.g. Bolan et al., 2013; Nixon et al., 2001), while the installation of photovoltaic systems (conventional or installed on flexible membranes) is another recently developed opportunity (USEPA, 2013; Mohapatra et al., 2012; Sampson, 2009). The use of closed landfill surfaces to grow energy crops presents excellent potential because this approach is compatible with landscape recovery processes and does not diminish the agricultural surfaces potentially usable for edible crops. Indeed, social, ethical and environmental points of view all suggest that the production of energy crops cannot compete with food crops cultivation (Rahman et al., 2014; Valentine et al., 2012). Thus, exploiting land that is unusable for conventional agriculture (e.g. landfills, contaminated sites, unproductive/marginal land) is the optimal alternative.

In this study, two scenarios are presented for the Valdina landfill: the installation of a photovoltaic system and the cultivation of giant reed (Arundo donax L.; Family: Poaceae; Subfamily: Arundinoideae; Tribe: Arundineae; Genus: Arundo; Species: Arundo donax) for energy production through combustion. For each scenario, the costs, potential energy production, avoided emissions and issues related to the integration of energy production with the landfill aftercare are evaluated.

Giant reed is a tall perennial cane growing in damp soils, either fresh or moderately saline. It is native of Eastern and Southern Asia, but it is also cultivated in the Mediterranean area. It is an asexually reproducing species because of the seed sterility, therefore, it is propagated by the rhizomes. In fact, it produces an extensive network of large but short rhizomes such as bulbs and fibrous taproots. Giant reed is one of the most promising crops for energy production that is grown in the Mediterranean climate. It shows advantages as an indigenous crop (i.e. it is already adapted to the environment), produces durable yields (up to 20 years), has exceptional soil carbon sequestration and adapts to saline soils and saline water. It also displays resistance to biotic and abiotic stresses as well as long drought periods and provides good protection against soil erosion. Moreover, dry biomass has a lower heating value of $17 \mathrm{GJ} \mathrm{t}^{-1}$.

In Italy, giant reed was used from 1937 to 1962 on a large-scale industrial basis for paper production and dissolving pulp, reaching an average annual production of $35 \mathrm{t} \mathrm{ha}^{-1}$. It produces energy through cocombustion with other combustibles (e.g. wood, coal); indeed, if used alone, the amount of silicon naturally present in this biomass would lead to scaling problems in the boiler. Recent studies also report the use of giant reed for the production of second-generation bioethanol (Scordia et al., 2009, 2012).

An additional benefit related to the cultivation of giant reed on an exhausted landfill site is using the produced leachate as a possible source of irrigation. The scientific literature has already demonstrated the high tolerance of giant reed to irrigation with highly concentrated aqueous solutions of heavy metals (Papazoglou, 2007).

\section{Valdina landfill}

The Valdina landfill (Figure 1) was built in 1998 in an exhausted clay pit in order to dispose of untreated mixed MSW, with approximately $85 \%$ of the total landfill capacity coming from the cities of Messina ( 250000 inhabitants), Milazzo ( 35000 inhabitants) and Barcellona Pozzo di Gotto ( 42000 inhabitants). Limited quantities of untreated mixed MSW also came from other towns in the province of Messina. In this area, because separate collection is very inefficient, mixed MSW is mainly (more than 50\%) composed of biodegradable waste (e.g. kitchen and garden waste, paper, cardboard, wood). 


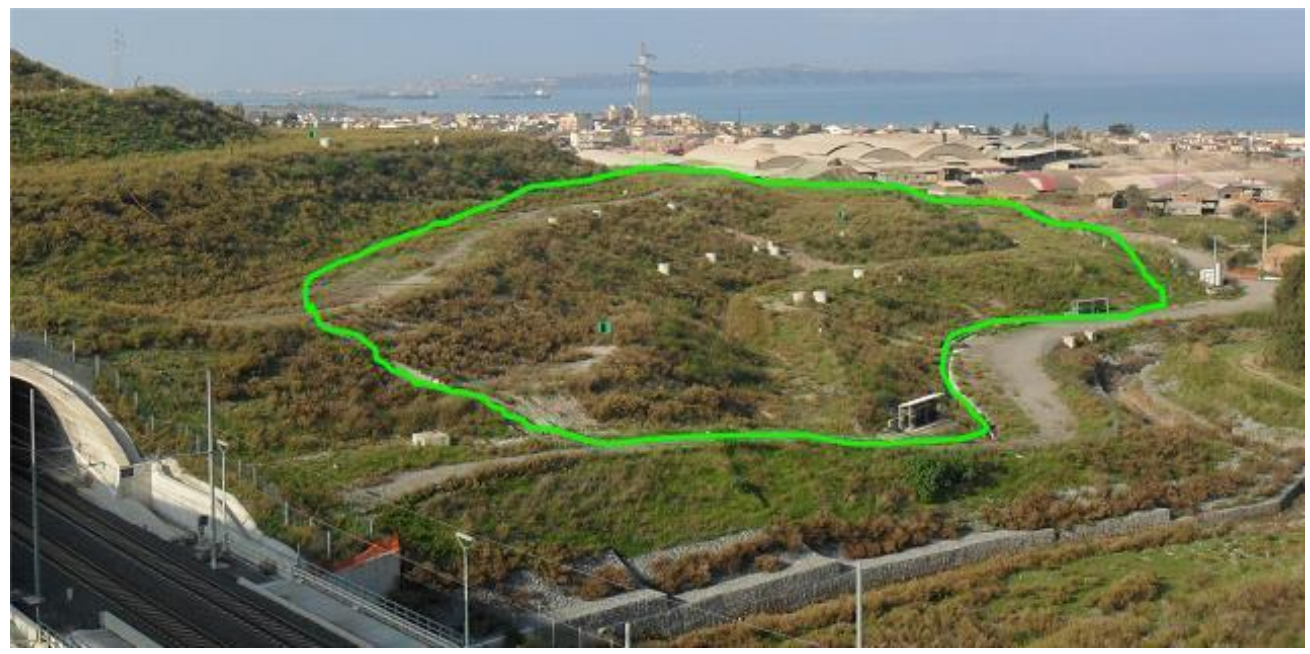

Figure 1. Valdina landfill

Table 1. Valdina landfill characteristics

\begin{tabular}{lc}
\hline Landfill characteristics & \\
\hline Surface [ha] & 2.59 \\
Perimeter [m] & 650 \\
Slope of the landfill $\left[^{\circ}\right]$ & 18 \\
Mass of landfilled waste [t] & 160602 \\
Maximum height of the waste layer [m] & 24 \\
Waste landfilled & Mixed MSW \\
Age of landfilled waste [year] & 16.5 \\
Average leachate production [t year & $-1]$ \\
Cost for leachate transport and disposal $\left[€ \mathrm{t} \mathrm{t}^{-1}\right]$ & 350 \\
\hline
\end{tabular}

Table 2. Valdina landfill leachate composition in the period 2011-2013

\begin{tabular}{|c|c|}
\hline Constituent & Concentration \\
\hline $\mathrm{pH}$ & 7,3 \\
\hline $\mathrm{BOD}_{5}\left[\mathrm{mg} \mathrm{l}^{-1}\right]$ & 171,7 \\
\hline Total COD [mg l-1] & 492,0 \\
\hline $\mathrm{BOD}_{5} / \mathrm{COD}$ & 0.35 \\
\hline Ammonium $\left[\mathrm{mg} \mathrm{l}^{-1}\right]$ & 371,0 \\
\hline As $\left[\mathrm{mg} \mathrm{l}^{-1}\right]$ & $<0.1$ \\
\hline $\mathrm{Cd}\left[\mathrm{mg} \mathrm{l}^{-1}\right]$ & $<0.1$ \\
\hline $\mathrm{Cr}$ tot $\left[\mathrm{mg} \mathrm{l}^{-1}\right]$ & $<0.1$ \\
\hline $\mathrm{Cu}\left[\mathrm{mg} \mathrm{l}^{-1}\right]$ & $<0.1$ \\
\hline $\mathrm{Hg}\left[\mathrm{mg} \mathrm{l}^{-1}\right]$ & $<0.1$ \\
\hline $\mathrm{Ni}\left[\mathrm{mg} \mathrm{l}^{-1}\right]$ & $<0.1$ \\
\hline $\mathrm{Pb}\left[\mathrm{mg} \mathrm{l}^{-1}\right]$ & $<0.1$ \\
\hline $\mathrm{Zn}\left[\mathrm{mg} \mathrm{l}^{-1}\right]$ & $<0.1$ \\
\hline
\end{tabular}

The amount of untreated mixed MSW disposed in this landfill between October 1998 and September 1999 was 160602 t. In September 1999, the landfill was closed, covered with a clay layer and topped with soil. The construction of a more complex engineered impermeable cover was not required by the landfill regulations effective in Italy during that period. Since then, the leachate produced in the landfill has been collected and transported to an external plant on the mainland (distance $\sim 80 \mathrm{~km}$ ) for treatment. The main characteristics of the landfill are reported in Table 1, while Table 2 reports the average characteristics of the leachate on the basis of the last three samples collected (December 2011, June 2012, 
July 2013) and analysed. Data presented in Table 2 show that $\mathrm{BOD}_{5} / \mathrm{COD}$ is compatible with actual waste stabilisation while the overall pollutant load associated with leachate is moderated if compared with literature data (Kjeldsen et al., 2002) especially if heavy metals are considered .

The biogas collection system of the Valdina landfill is constituted by 27 vertical wells connected to a torch for the combustion of biogas; unfortunately, data on biogas production and composition are not available.

\section{Material and methods}

\subsection{Biogas production simulation}

Because data on biogas/methane production in the Valdina landfill are not available, a mathematical model was used for its quantification. The chosen model, the USEPA LandGEM model (USEPA, 2005), is well known and widely used. During the modelling stage, it was assumed that the biogas was composed of equal amounts in volume of $\mathrm{CH}_{4}$ and $\mathrm{CO}_{2}$. The USEPA LandGEM model requires two parameters, namely the specific methane yield $\mathrm{L}_{0}\left[\mathrm{~m}^{3}{ }_{\text {methane }} t_{\text {waste }}{ }^{-1}\right]$ and the first-order kinetic constant $\mathrm{k}$ [year $\left.{ }^{-1}\right]$. However, owing to the lack of specific measurement, these parameters were set to the inventory values suggested by the user guide (USEPA, 2005), namely $100 \mathrm{~m}^{3}$ methane $\mathrm{t}_{\text {waste }}{ }^{-1}$ and 0.04 year $^{-1}$, respectively.

Because the biogas in the Valdina landfill is burned in a torch, the presence of a biogas management system with energy recovery was hypothesised for the purpose of this study. In fact, the reduction of the impact of the greenhouse gas emissions emitted from a landfill site cannot exclude the presence of an efficient system for the collection and energy exploitation of the biogas produced. The efficiency of the biogas collection system is thus a key issue when dealing with the problems associated with greenhouse gas emissions from a landfill; however, this is very difficult to assess. The examined literature (Calabrò, 2009 and references therein) reports biogas collection efficiency levels from $30 \%$ to $90 \%$ depending on several factors, such as the timing of the system construction (after or during the filling of the landfill), system type (active or passive), adopted layout (number and position of biogas collecting wells), design accuracy, construction and management. For these reasons three levels of biogas collection efficiency $(30 \%, 50 \%$ and $75 \%)$ were chosen for the hypothetical biogas management system of the Valdina landfill. The scenarios simulated are summarized in Table 3.

Table 3. Biogas management scenarios

\begin{tabular}{l|c|c|c}
\hline & $\begin{array}{c}\text { Scenario 0 } \\
\text { Real situation }\end{array}$ & $\begin{array}{c}\text { Scenario 1 } \\
\text { Hypothetical }\end{array}$ & $\begin{array}{c}\text { Scenario 2 } \\
\text { Hypothetical }\end{array}$ \\
\hline $\begin{array}{l}\text { Natural methane } \\
\text { oxidation* }\end{array}$ & $10 \%$ & $10 \%$ & $10 \%$ \\
\hline $\begin{array}{l}\text { Methane Collection } \\
\text { efficiency }\end{array}$ & $30 \%$ & $50 \%$ & $75 \%$ \\
\hline $\begin{array}{l}\text { Management of methane } \\
\text { collected }\end{array}$ & Torch combustion & Electricity production & Electricity production \\
\hline $\begin{array}{l}\text { Methane emission } \\
\text { *Stern } \text { et al., 2007 }\end{array}$ & $60 \%$ & $40 \%$ & $15 \%$ \\
\hline
\end{tabular}

The energy production using biogas is esteemed according to Calabrò (2009), considering an energy production of $1473.4 \mathrm{kWh} \mathrm{t}_{\text {biogas }}{ }^{-1}$ while avoided emissions are calculated considering that the generation of $1 \mathrm{kWh}$ of electricity prevents the emission of $0.527 \mathrm{kgCO}_{2}$ (average emission factor for Italy; Calabrò, 2009).

\subsection{Pot experiment for testing the cultivation of giant reed by using leachate for irrigation}

To evaluate the feasibility of cultivation of giant reed on Valdina landfill, a preliminary pot experiment was carried out: 18 rhizomes coming from a spontaneous local cane thicket were selected (the weights and dimensions of the different rhizomes were similar) and planted in six plastic pots (volume $15 \mathrm{l}$, height about $30 \mathrm{~cm}$ ) filled with soil mixed $(50 / 50)$ with commercial compost. The replications aided to check the 
statistical relationship between the final height of the culms using analysis of variance principles (ANOVA). For the first month, the pots were irrigated with water only $\left(360 \mathrm{ml}^{\text {week }}{ }^{-1}\right)$. After this period, in some cases water was partially or totally substituted by the leachate as indicated in Table 4 . Water drained from each pot after irrigation was collected and recirculated in the same container.

A sample of real leachate, sufficient for the whole irrigation programme (about $15 \mathrm{I}$ ), was collected from the Valdina landfill. Since its nitrogen and heavy metal content was very low compared with the ranges reported in literature (Renou et al., 2008; Kjeldsen et al., 2002), ammonium, copper, nickel and zinc chloride (Sigma Aldrich, purity $>99,5 \%$ ) were added. The final leachate composition is presented in Table 5.

Table 4. Irrigation scenarios .

\begin{tabular}{|c|c|c|c|c|}
\hline Pot ID & $\begin{array}{c}\text { Month } 1 \\
\text { Water }\left[\mathrm{ml} \text { week }^{-1}\right]\end{array}$ & 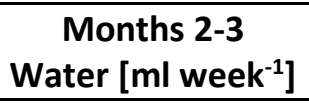 & $\begin{array}{c}\text { Months 2-3 } \\
\text { Leachate }\left[\mathrm{ml} \text { week }^{-1}\right]\end{array}$ & $\begin{array}{c}\text { \% Leachate } \\
\text { Substitution* }\end{array}$ \\
\hline$A-B$ & 360 & 360 & 0 & 0 \\
\hline C & 360 & 240 & 120 & $33 \%$ \\
\hline D & 360 & 180 & 180 & $50 \%$ \\
\hline$E-F$ & 360 & 0 & 360 & $100 \%$ \\
\hline
\end{tabular}

*Percentage of irrigation water substituted by leachate

Table 5. Composition of the semi-synthetic leachate used for irrigation .

\begin{tabular}{lc}
\hline & Concentration $\left[\mathrm{mg} \mathrm{l}^{-1}\right]$ \\
\hline $\mathbf{p H}$ & 7.8 \\
Ammonia Nitrogen & 255 \\
Chloride & 1380 \\
$\mathrm{Cu}$ & 5 \\
$\mathrm{Ni}$ & 9 \\
$\mathrm{Zn}$ & 5 \\
\hline
\end{tabular}

After harvesting the reeds, samples were collected and powdered $(<1 \mathrm{~mm})$ by using a cutting mill (Fritsch Pulverisette 15) in order to verify the distribution of heavy metals in the various parts of the plant (rhizome/roots and culms) and soil. Then, water and nitric acid were added in order to reach an I $\mathrm{S}^{-1}$ ratio of $10 \mathrm{I} \mathrm{kg}^{-1}$ and a pH of 3.5. The container was then sealed and agitated with a rotating stirrer (Rotator Drive STR 4/1) for 24 hours. Next, the liquid samples were centrifuged and filtered $(0.45 \mu \mathrm{m}$ filter) and then analysed to measure the aqueous concentrations of $\mathrm{Cu}, \mathrm{Ni}$ and $\mathrm{Zn}$ by atomic absorption spectrophotometry (Shimadzu AA - 6701F) using conventional methods (APHA, 2005).

\subsection{Electricity production by using a conventional photovoltaic system installed on the landfill site}

As an alternative to the use of the landfill surface for the production of biofuels, the construction of a conventional photovoltaic system was considered. The term conventional is used since traditional panels mounted on stands are employed. The use of such panels is more consolidated and safer compared with the flexible modules recently placed directly onto landfill covers. The used surface was 1 ha owing to the cost, configuration of the landfill surface and technical and economic constraints for the installation of the photovoltaic modules (e.g. high slopes, need for space to install and maintain the system, problems related to landfill settlement and to the load induced on the landfill cover), which prevent higher surface use (e.g. Tansel et al., 2013; USEPA, 2013; Sampson, 2009).

Energy production and installation costs were calculated by using the computer software PVSol (PVSol, 2012). This software includes a library of data on solar radiation intensity for Italy, particularly the province of Messina. The adopted photovoltaic module was a current silicon single crystal that had an efficiency of $14.4 \%$. 


\section{Results}

\subsection{Biogas management scenarios}

Figure 2 presents the results of the simulations carried out by using the USEPA LandGEM model in terms of biogas, methane and carbon dioxide production, while Table 6 gives the total production. Table 7 shows the key parameters for evaluating the three biogas management scenarios considered in this study.

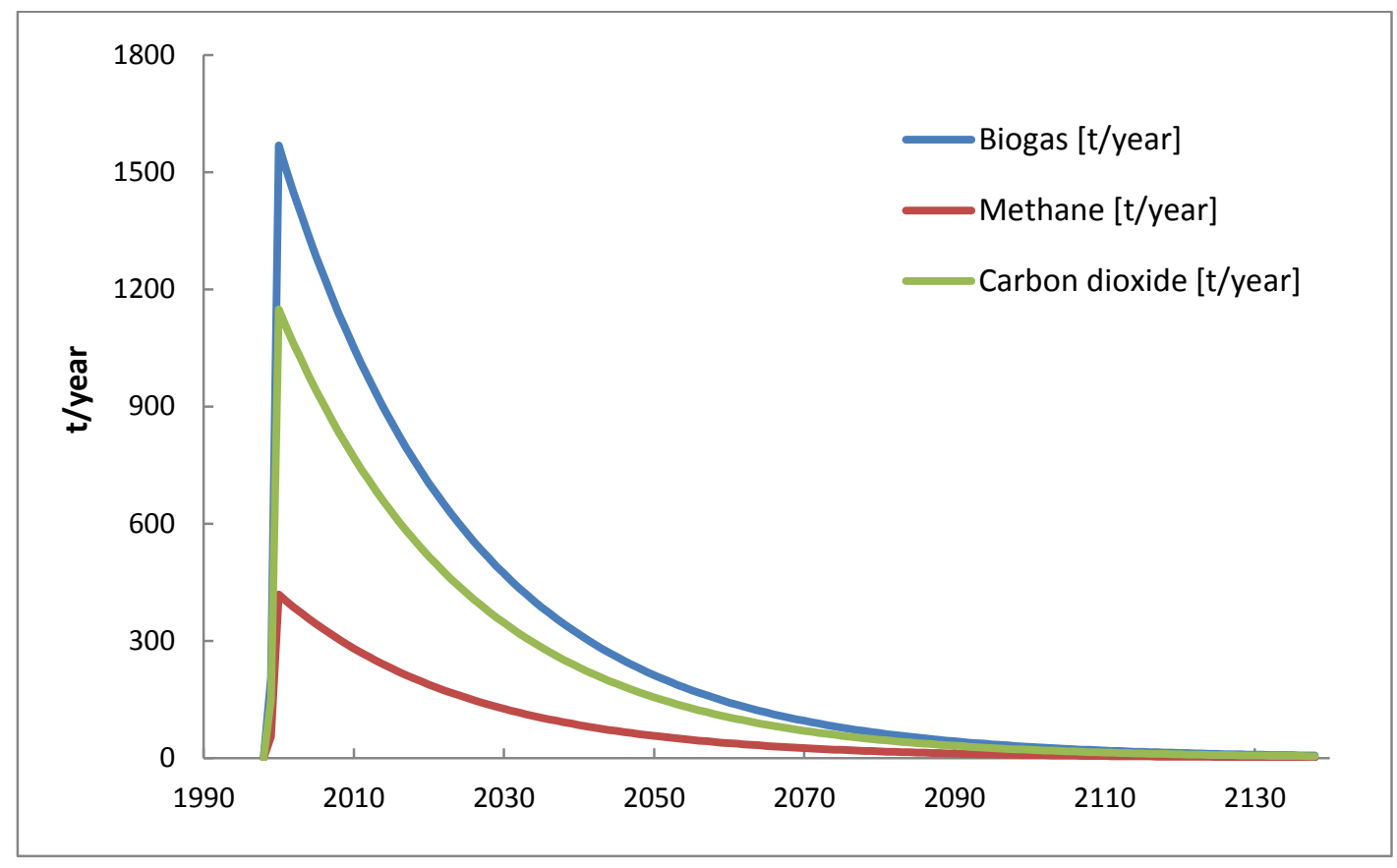

Figure 2. Simulated biogas production in the Valdina landfill.

Table 6. Simulated biogas production in the Valdina landfill over 100 years.

\begin{tabular}{lc}
\hline & Total Production [t] \\
\hline Biogas & 39500 \\
$\mathrm{CH}_{4}$ & 10500 \\
$\mathrm{CO}_{2}$ & 29000 \\
\hline
\end{tabular}

Table 7. Scenarios of greenhouse gas emissions from the Valdina landfill.

\begin{tabular}{lccc}
\hline & Scenario 0 & Scenario 1 & Scenario 2 \\
\hline Methane oxidised [t] & 1050 & 1050 & 1050 \\
Methane collected [t] & 3150 & 5250 & 7875 \\
Methane emitted [t] & 6300 & 4200 & 1575 \\
Equivalent emissions* [tCO & 132300 & 88200 & 33075 \\
Energy production [GWh] & 0 & 29497 & 44245 \\
Net emissions** [tCO $\mathrm{tCO}_{2 \text { eq }}$ & 132300 & 59300 & -10300 \\
\hline
\end{tabular}

*Emission of methane converted into equivalent emission of $\mathrm{CO}_{2}$ multiplying the amount of $\mathrm{CH}_{4}$ emitted by 21 (methane global warming potential)

**Net emission are obtained by subtracting the avoided emissions due to energy production from the equivalent emission due to methane

Results presented in Table 7 show that for Scenario 2, thanks to the very high biogas collection efficiency, energy production completely compensates methane emissions(net emissions are negative) but such a system is very difficult to implement in practice (e.g. construction and management of collection system, feasibility of energy production due to extremely varying gas flow). 


\subsection{Results of the pot experiment}

The analysis of the culms harvested at the end of the experiment showed that the samples (independent of the irrigation regime) present $14 \%$ dry matter and $8 \%$ ashes after complete combustion at $900^{\circ} \mathrm{C}$. Although the results presented in Table 8 must be considered to be preliminary, as confirmed by ANOVA at $p<0.01$, they imply that the use of leachate for the irrigation of giant reed during its initial growth does not significantly affect the amount of biomass produced or the dimensions of the culms. Moreover, the analysis of the harvested biomass showed that metals tend to be concentrated in soil and roots, while their presence in culms is limited (Han, 2006); only 1-2\% of the total metal content of the pot (culms, rhizomes and soil) is attributable to culms.

These results, although preliminary, showed that the irrigation of giant reed cultivation with the leachate produced in the post-closure period may be feasible without significantly affecting the amount and quality of the biomass, confirming the findings reported by Papazoglou 2007 and Papazoglou; 2009. However, further experiments are needed to verify the long-term effect of this practice.

Table 8. Results of the pot experiments

\begin{tabular}{cccc}
\hline \% Leachate & $\begin{array}{c}\text { Aver. biomass production per pot } \\
\text { (culms - wet weight) [g] }\end{array}$ & Average Culm Height [cm] & $\begin{array}{c}\text { Aver. Culm } \\
\text { Diameter [cm] }\end{array}$ \\
\hline $\mathbf{0 \%}$ & 32 & 32 & 1,3 \\
\hline $\mathbf{3 3 \%}$ & 31 & 29,3 & 0,9 \\
\hline $\mathbf{5 0 \%}$ & 31 & 30,3 & 1,1 \\
\hline $\mathbf{1 0 0 \%}$ & 30 & 31 & 0,8 \\
\hline
\end{tabular}

According to the relevant literature (Candolo, 2009), the average annual cost to cultivate giant reed on 2.5 ha of the Valdina landfill for 20 years would be about $5000 €$ year $^{-1}$. Table 9 summarises the possible output from this cultivation, considering an average production of $25 \mathrm{t}_{\text {dry }}$ matter $y e a r^{-1}$, a lower heating value of $17 \mathrm{GJ} \mathrm{t}^{-1}$ and an electricity conversion efficiency of $25 \%$.

Table 9. Possible output of giant reed cultivation on the Valdina landfill

\begin{tabular}{lcc}
\hline & Yearly basis & 20-year basis \\
\hline Biomass production [ $\mathbf{t}_{\text {dry matter }}$ ] & 63 & 1250 \\
\hline Energy production $[\mathbf{M W h}]$ & 74 & 1480 \\
\hline Avoided emission $\left[\mathbf{t}_{\text {cozeq }}\right.$ ] & 39 & 778 \\
\hline Energy cost [ $\mathbf{~ k W h}^{-1}$ ] & & 0.1 \\
\hline
\end{tabular}

\subsection{Photovoltaic plant output}

Table 10 summarises the main characteristics of the plant. The energy production of photovoltaic systems is highly dependent on local conditions (e.g. the efficiency and exposition of the module, solar radiation intensity); however the energy production hypothesised for the Valdina landfill is compatible with the results reported by Tansel et al. (2013) from a case study in Florida.

Table 10. Energy production by the photovoltaic plant.

\begin{tabular}{ccc}
\hline & Yearly basis & 20-year basis \\
\hline Installed power $\left[\mathbf{k W}_{\mathrm{p}}\right]$ & \multicolumn{3}{c}{1840} \\
\hline Energy production $[\mathrm{MWh}]$ & 2638 & 52760 \\
\hline Avoided emission $\left[\mathbf{t}_{\text {co2eq }}\right]$ & 1390 & 27804 \\
\hline Energy cost $\left[\boldsymbol{\epsilon} \mathbf{~} \mathbf{W h}^{-1}\right]$ & & 0.27 \\
\hline
\end{tabular}

According to the outputs of the computer software used, the initial cost of the plant is $8,3 \mathrm{M} €$, while the operation and maintenance cost is $58000 €$ year $^{-1}$. Considering an interest on capital of $\sim 5 \%$, the amortisation of the initial cost would be completed in about 15 years. All calculations are, however, based on the hypothesis that the overpricing policy for renewable energy is maintained in the next 20 years therefore the convenience of installation of a photovoltaic plan on an exhausted landfill is mainly based 
on financial considerations.

\section{Discussion}

\subsection{Comparison of the alternatives}

The results in terms of electricity production and emission compensation by either the combustion of giant reed or the photovoltaic system are presented in Table 11. Energy production, avoided emissions and, as a consequence, the capacity to compensate for the greenhouse gas emissions from the Valdina landfill are about 35 times higher when using the photovoltaic system compared with cultivating and combusting giant reed. By contrast, the installation cost for this type of plant is extremely high and the produced energy costs about three times more than the energy produced from giant reed. In fact, as already mentioned, the economic convenience of solar energy is still based on the fact that very high incentives are guaranteed to producers that increase production of renewable energy. Without these incentives, the production of electricity by photovoltaic systems would be economically infeasible. Further, the cost of the energy produced by giant reed is of the same order of magnitude as that of traditional, non-renewable, energy sources (i.e. $0,022 € \mathrm{kWh}^{-1}$ from fossil coal; $0.055 € \mathrm{kWh}^{-1}$ from oil; $0.063 € \mathrm{kWh}^{-1}$ from natural gas; Assocarboni, 2012). Moreover, the productivity of giant reed and efficiency of the electricity conversion assumed in the calculations are very conservative; therefore, in favourable conditions, the final price of electricity could be comparable with that of oil and natural gas.

The cultivation of giant reed also poses minor problems with respect to the stabilisation (i.e. waste settlement and biodegradation) and landscape reclamation (e.g. vegetable cover, visual impact) of the landfill compared with the installation of a photovoltaic plant. Giant reed could be cultivated on a temporary cover almost immediately after the closure of the landfill while the cultivation on the final cover is more complex, especially if leachate is used for irrigation, because the root systems of the selected crop must be compatible with the cover system, while the leachate/drainage water not absorbed by the soil must be collected and managed (e.g. recirculated or treated). On the contrary, the construction of a photovoltaic plant requires the settlement of the waste to be complete, the final cover to be installed and the foundations of the panels' stands to be fully compatible with it. Moreover the emissions due to the construction, management and disposal of the photovoltaic system and its aesthetic impact must be taken into account when planning this type of investment.

In addition, the leachate-based irrigation of giant reed cultivated on a temporary cover can increase the humidity of landfilled waste, promoting faster waste biodegradation according to the bioreactor landfill concept (Reinhart et al., 2002). Moreover, the agricultural use of landfill topsoil can increase natural methane oxidation (Hilger et al., 2000).

Table 11. Comparison of energy crop cultivation and the installation of a photovoltaic plant.

\begin{tabular}{lcc}
\hline & Giant reed & Photovoltaic Plant \\
\hline Energy production [MWh] & 1480 & 52760 \\
Avoided emissions [t cozeq $^{\text {] }}$ & 778 & 27804 \\
Emission compensation for Scenario 0 & $2.4 \%$ & $84.1 \%$ \\
Emission compensation for Scenario 1 & $5.2 \%$ & $187.5 \%$ \\
Initial investment [ $€$ ] & 18,000 & $8,300,000$ \\
Operation and maintenance cost [ $\boldsymbol{\epsilon}_{\text {year }}{ }^{-1}$ ] & 4,100 & 58,000 \\
Energy cost [ kWh $^{-1}$ ] & 0.10 & 0.27 \\
\hline Data presented are referred to an expected lifespan of both the giant reed cane thicket and the \\
photovoltaic plant of 20 years.
\end{tabular}

From an economic point of view, considering the case of the Valdina landfill and hypothesising that only $50 \%$ of the leachate produced is used for irrigation (during the rainy months of between November and February, irrigation is not possible), a saving of about $13,000 €$ year- 1 is achievable. According to the hypothesis that the produced biomass does not produce an income, this saving covers the initial 
investment within two years and, considering only operation and maintenance costs, a net saving of about $10,000 €$ year- 1 is possible for landfill owners.

\section{Conclusions}

In this study, two scenarios for the energy exploitation of a closed landfill were presented with reference to the Valdina landfill in Italy: the installation of a photovoltaic system and the cultivation of giant reed for energy production through combustion. According to a preliminary experimental activity, leachate produced in the Valdina landfill could be used for the purposes of giant reed irrigation. Of these two options, energy production through the photovoltaic system provides the best compensation of greenhouse gas emissions, but giant reed cultivation is more economically sustainable over a long period and well integrated with landfill management in the early post-closure period.

Therefore, the presented results suggest that giant reed cultivation, especially if leachate is used for irrigation, is a feasible approach for the partial compensation of the greenhouse gas emissions generated by waste disposal, especially in the early post-closure period after the installation of a temporary cover. However, installing a photovoltaic plant could become more convenient if evidence that the mechanical and biochemical stabilisation of waste arises (i.e. the negligibility of the settlement rate and biogas emissions) and if the investment is sustainable/convenient for the landfill owner.

\section{Acknowledgements}

The authors are grateful to Dr. Giuseppe Panzera, Eng. Angela Fedele and Eng. Annalisa Monorchio for their essential help during the experimental activity.

\section{References}

APHA, AWWA and WEF (2005), Standard Methods for the examination of water and wastewater, $21^{\text {st }}$ ed. American Public Health Association, Washington D.C. (USA).

Assocarboni (2012), I vantaggi del Carbone (Coal Advantages). Internet site: http://www.assocarboni.it/index.php/it/il-carbone/i-vantaggi-del-carbone (accessed: 06/02/2014).

Bolan N.S., Thangarajan R., Seshadri B., Jena U., Das K.C., Wang H. and Naidu R. (2013), Landfills as a biorefinery to produce biomass and capture biogas, Bioresource Technology, 135, 578-587.

Calabrò P.S. (2009), Greenhouse gases emission from municipal waste management: The role of separate collection, Waste management, 29(7), 2178-2187.

Candolo G. (2009), Aspetti agronomici e costi di produzione di alcune colture agroenergetiche. (Agronomic aspects and production costs of some energy crops) Internet site: http://first.aster.it/doc09/eventi/progetto_renewed/pomeriggio/Candolo_Terremerse_ costi_biomasse_agricole.pdf (accessed: 06/02/2014).

Gazzetta Ufficiale della Repubblica Italiana (2003), Decreto legislativo 13 gennaio 2003, n. 36. Attuazione della direttiva 1999/31/CE relativa alle discariche di rifiuti, Gazzetta Ufficiale della Repubblica Italiana n. 59 del 12.03.2003, Suppl. Ordinario n.40.

Han Z.P. (2006), Accumulation and Distribution of Chromium, Copper and Nickel in Arundo donax Linn, Environmental Science \& Technology, 29(5), 106-108.

Hilger H.A., Wollum A.G. and Barlaz M.A. (2000), Landfill Methane Oxidation Response to Vegetation, Fertilization, and Liming, Journal of Environmental Quality, 29(1), 324-334.

Kjeldsen P., Barlaz M.A., Rooker A.P., Baum A., Ledin A. and Christensen T.H. (2002), Present and long-term composition of msw landfill leachate: a review, Critical Reviews in Environmental Science and Technology, 32(4), 297-336.

Mohapatra P., Ali S.M., Mishra S.P. and Pradhan A. (2012), Future aspects of solar panel installation on closed landfill, International Journal of Advances in Engineering \& Technology, 4(2), 324-332.

Nixon D.J, Stephens W., Tyrrel S.F. and Brierley E.D.R (2001), The potential for short rotation energy forestry on restored landfill caps, Bioresource Technology, 77(3), Pages 237-245. 
Official Journal of the European Community (1999), Council Directive 1999/31/EC of 26 April 1999 on the landfill of waste, Official Journal L 182 , 16/07/1999, 1-19.

Papazoglou E.G. (2007), Arundo Donax L. stress tolerance under irrigation with heavy metal aqueous solutions, Desalination, 211, 304-313.

Papazoglou E.G. (2009), Heavy metal allocation in giant reed plants irrigated with metalliferous water, Fresenius Environmental Bulletin, 18, 166-174.

PVSol (2012), Software for the design of photovoltaic systems. Internet site: http://www.valentin.de/it/node/730 (accessed: 06/03/2013).

Rahman M.M., Mostafiz S.B., Paatero J.V. and Lahdelma R. (2014), Extension of energy crops on surplus agricultural lands: A potentially viable option in developing countries while fossil fuel reserves are diminishing, Renewable and Sustainable Energy Reviews, 29, 108-119.

Reinhart D.R., McCreanor P.T. and Townsend T. (2002), The bioreactor landfill: its status and future, Waste Management and Research, 20(2), 172-186.

Renou S., Givaudan J.G., Poulain S., Dirassouyan F., Moulin P. (2008), Landfill leachate treatment: Review and opportunity, Journal of Hazardous Materials, 150(3), 468-493.

Sampson G. (2009), Solar Power Installations on Closed Landfills: Technical and Regulatory Considerations. U.S. Environmental Protection Agency, Office of Solid Waste and Emergency Response. Internet site: http://clu-in.org/download/studentpapers/Solar-Power-Installations-on-Closed-Landfills-Sampson.pdf. Accessed: 21/05/2014.

Scordia D., Cosentino S.L., Lee J.W. and Jeffries T.W. (2012), Bioconversion of giant reed (Arundo donax L.) hemicellulose hydrolysate to ethanol by Scheffersomyces stipitis CBS6054, Biomass and bioenergy, 39, 296 - 305.

Scordia D., Jeffries T.W., Copani V. and Cosentino S.L. (2009), Production of second generation bioethanol from giant reed (Arundo donax L.), Proceedings of $17^{\text {th }}$ European Biomass Conference and Exibition, Hamburg, Germany. ISBN/ISSN 978-88-89407-57-3.

Stern J.C., Chanton J., Abichou T., Powelson D., Yuan L., Escoriza S. and Bogner J. (2007), Use of a biologically active cover to reduce landfill methane emissions and enhance methane oxidation, Waste Management, 27(9), 1248-1258.

Tansel B., Kumar Varala P. and Londono V. (2013), Solar energy harvesting at closed landfills: Energy yield and wind loads on solar panels on top and side slopes, Sustainable Cities and Society, 8, 42-47.

USEPA (2005). Landfill Gas Emissions Model (LandGEM) Version 3.02 User's Guide, EPA-600/R-05/047. Available from: http://www.epa.gov/ttncatc1/dir1/landgem-v302-guide.pdf

USEPA (2013), Best Practices for Siting Solar Photovoltaics on MSW Landfills, U.S. Environmental Protection Agency, National Renewable Energy Laboratory. Internet site:

http:/www.epa.gov/oswercpa/docs/best_practices_siting_solar_photovoltaic_final.pdf. Accessed: 21/05/2014.

Valentine J., Clifton-Brown J., Hastings A., Robson P., Allison G. and Smith P. (2012), Food vs. fuel: the use of land for lignocellulosic 'next generation' energy crops that minimize competition with primary food production, $G C B$ Bioenergy, 4(1), 1-19. 